\title{
COMMENTS
}

\section{Preclusive Abstention: Issue Preclusion and Jurisdictional Dismissals after Ruhrgas}

\author{
Michael J. Edney†
}

This Comment addresses the preclusive effect of a federal court's judgment when that court lacks subject matter jurisdiction. This situation arises when a court either (1) explicitly finds that it lacks subject matter jurisdiction or (2) defers determining its subject matter jurisdiction and dismisses on other grounds. These two classes of cases isolate and dispatch the questions of waiver and vertical appellate exhaustion,' and raise a common question: To what extent, if at all, may a federal court preclude the litigation of issues in another court if the federal court lacks subject matter jurisdiction in the first instance?

The first case is a common one: federal courts regularly dismiss or remand cases for lack of subject matter jurisdiction. ${ }^{2}$ These dismissals

$\dagger$ B.A. 1998, University of Notre Dame; J.D. Candidate 2001, The University of Chicago.

1 Perhaps inevitably, federal courts often enter judgments on the merits either by erroneously finding or without considering their own subject matter jurisdiction. In both cases, the law is fairly well-settled. When a court explicitly finds that it has subject matter jurisdiction and that finding is upheld or unchallenged on appeal, that judgment cannot typically be attacked in another court for lack of subject matter jurisdiction. See Durfee v Duke, 375 US 106, 116 (1963) (holding that a court has power to inquire into jurisdiction of another court to render a decision, but that further inquiry is precluded once it is found that jurisdictional issues have been decided). See also Part I.A. Moreover, that subject matter jurisdiction was neither raised nor explicitly decided does not expose the judgment to collateral attack. Although an objection to subject matter jurisdiction generally may be raised at any time, either by the parties or by the court sua sponte, see Capron v Van Noorden, 6 US (2 Cranch) 126, 127 (1804), it is waived if not raised by the end of vertical appeals from the trial court judgment. See Cutler $v$ Hayes, 818 F2d 879, 888-89 \& n 72 (DC Cir 1987) (noting that all valid jurisdictional judgments have preclusive effect). This Comment leaves those settled issues aside. But see United States $v$ United States Fidelity \& Guaranty Co, 309 US 506, 513-14 (1940) (holding that Indian tribe immunity, which is "jurisdictional," cannot be waived by the failure to raise it and is the appropriate subject of collateral attack). For an attempted reconciliation of these cases, see Edward P. Krugman, Note, Filling the Void: Judicial Power and Jurisdictional Attacks on Judgments, 87 Yale L J 164, 222 (1977) (arguing that the voidness doctrine, which provides that a judgment of a court without subject matter jurisdiction is without effect, is outdated and no longer good law).

2 See FRCP 12(b)(1) (providing for a motion to dismiss for lack of subject matter jurisdiction before filing a responsive pleading). 
usually preclude relitigation of the "precise issue" of whether federal courts have subject matter jurisdiction over the cause of action. ${ }^{3}$ The more controversial question is whether or to what extent these dismissals also preclude relitigation of the questions of law and fact on the merits which were "actually litigated" and "necessarily decided" to determine the lack of subject matter jurisdiction. When federal courts find a lack of subject matter jurisdiction, should those courts only be able to preclude the relitigation of their subject matter jurisdiction?

The second case in which a court explicitly defers the question of its subject matter jurisdiction and takes final action on other grounds has only recently become a possibility. In Ruhrgas AGv Marathon Oil $C o$, the Supreme Court held that a federal court may dismiss a case for lack of personal jurisdiction before, and ultimately without, deciding whether it has subject matter jurisdiction over the cause of action. ${ }^{6}$ Although the Court in Ruhrgas found that a federal court is able to dismiss for want of personal jurisdiction instead of subject matter jurisdiction because either finding merely prevents federal adjudication

3 See notes $124-25$.

4 Preclusion rules attach a degree of finality to the judgment of a court. There are two general classes of preclusion: (1) claim preclusion (or res judicata) and (2) issue preclusion (or collateral estoppel). Both classes of preclusion rules are designed to prevent the inefficient or duplicative litigation of questions already settled, to protect litigants from vexatious relitigation by vanquished parties, and to save the judicial system from dealing with inconsistent verdicts between two parties. See, for example, Montana v United States, 440 US 147, 153-54 (1979); Bilida v McCleod, 211 F3d 166, 170 (1st Cir 2000). With regard to the second class of preclusion-issue preclusion-there are generally two requirements for the decision of an issue in a prior ruling to preclude the relitigation of that issue in a second proceeding. The issue must generally have been "actually litigated" and "necessarily decided" in the first proceeding. See Bilida, 211 F3d at 170; Restatement (Second) of Judgments $\$ 27$ (1982).

The requirement that the issue be "necessarily decided" means that the issue must have been "essential" to the court's disposition of the case, rather than merely "decided" by the first court. See Restatement (Second) of Judgments $\$ 27$. Under this test, many issues litigated by the parties and decided by the court cannot form the basis for issue preclusion because the court likely did not rely on those rulings finally to dispose of the case. For example, judgments on alternative grounds may not form the basis for issue preclusion because it would be impossible to determine which rationale was indispensable to the result and therefore "necessarily decided." See id at cmt i.

With regard to subject matter jurisdiction dismissals, the general rule requiring that the issue to be precluded have been "necessarily decided" would excise several issues from prospective issue preclusive effect without further analysis. This Comment asks whether the preclusive effect of such jurisdictional dismissal is even narrower than the general "necessarily decided" rule would indicate.

5526 US 574 (1999).

6 Id at 578. In doing so, the Court repudiated one circuit's interpretation of Steel Co $v$ Citizens for a Better Environment, 523 US 83 (1998), that a federal court must determine its subject matter jurisdiction before dismissing on personal jurisdiction grounds. See Ruhrgas, 526 US at 582-83. The Court in Steel Co invalidated the concept of "hypothetical jurisdiction," holding that a federal court may not defer the resolution of a subject matter jurisdiction question to resolve an easier question on the merits, even if both would result in a dismissal. Steel Co, 523 US at 93-95. 
of the case on the merits, the Court left open the question of whether such a personal jurisdiction dismissal would preclude relitigation of a state's personal jurisdiction in state court. ${ }^{8}$ The Ruhrgas dismissal presents for the first time the question of issue preclusion where subject matter jurisdiction is not actually decided.' While federal courts, even before Ruhrgas, could decide certain issues before subject matter jurisdiction, those issues either also concerned the allocation of judicial power between federal and state courts, or had no substantive analogues, and therefore no potential for preclusive effect, outside of federal court. ${ }^{10}$

This Comment suggests that the preclusive effect of jurisdictional dismissals - where a federal court has either found a lack of subject matter jurisdiction or explicitly deferred the question of its subject matter jurisdiction-should be confined to the precise question of the federal court's jurisdiction. So limiting the preclusive effect would prevent federal courts from precluding litigation on the merits or of personal jurisdiction in state courts when their subject matter jurisdiction is uncertain. In this sense, this Comment argues that federal courts should engage in "preclusive abstention" - that is, the development of rules of preclusion which confine the preclusive effect of such dismissals to federal court - in order to avoid invading the important state interests in the independent adjudication of controversies typically protected by the limited subject matter jurisdiction of federal courts.

Part I explains why preclusion of state court litigation by federal courts, when a federal court denies or explicitly defers determining subject matter jurisdiction, was not a possibility before Ruhrgas. This Part also explains why the traditional rules of jurisdictional finality fail to deal with this new possibility. In Part II, this Comment argues that developing preclusion rules sensitive to the concerns of federalism is within the power of federal courts because the law governing the preclusive effect of federal judgments is federal law. Finally, in Part III, this Comment suggests that such federalism-sensitive preclusion rules

7 Ruhrgas, 526 US at 585.

8 Id ("If a federal court dismisses a removal case for want of personal jurisdiction, that determination may preclude the parties from relitigating the very same personal jurisdiction question in state court.") (emphasis added).

9 Even when federal courts do not explicitly find subject matter jurisdiction, rules of jurisdictional finality presume from silence, perhaps extravagantly, that the federal court decided it had jurisdiction. See, for example, Chicot County Drainage District v Baxter State Bank, 308 US 371, 376-78 (1940) (holding that a court's silence as to its jurisdiction does not expose its judgment's validity to collateral attack). In Ruhrgas dismissals, the federal court's explicit deferral of the subject matter jurisdiction question rebuts this presumption, perhaps permitting collateral challenge of the dismissal in state court.

10 See notes 26-30 and accompanying text. 
create the only result consistent with the nature of subject matter jurisdiction as the power finally to preclude litigation in state courts, the limited jurisdiction of a federal court to decide its own jurisdiction, and the procedures by which a federal court determines jurisdictional questions.

\section{RUHRGAS AND THE POTENTIALLY EXPANDING SCOPE OF PRECLUSION WITHOUT SUBJECT MATTER JURISDICTION}

\section{A. The Law of Jurisdictional Finality before Ruhrgas}

Traditionally, judgments that were "final, valid, and on the merits" were res judicata, precluding relitigation of any claims in a separate court which were or could have been raised in the first case. ${ }^{11}$ A lack of subject matter jurisdiction affected this traditional formula for both judgments on the merits rendered amidst uncertainty regarding subject matter jurisdiction and dismissals on jurisdictional grounds.

First, judgments were not "valid" unless the rendering court had jurisdiction over both the subject matter and the person. ${ }^{12}$ Thus, at first glance, it would appear a judgment could never be claim preclusive when possible subject matter jurisdiction defects exist since it would never be "valid." In response to potentially endless relitigation of the rendering court's subject matter jurisdiction, the Supreme Court developed the doctrine of jurisdictional finality. ${ }^{13}$ Under the doctrine of jurisdictional finality, a lack of subject matter jurisdiction is not grounds for collaterally challenging a final judgment and preventing its claim preclusive effect. ${ }^{14}$ If the rendering court decided that it had subject matter jurisdiction, that determination would be final and could not be collaterally challenged in another court..$^{\text {If }}$ If the rendering

11 Federated Department Stores, Inc v Moitie, 452 US 394, 398 (1981) (“A fixed judgment on the merits of an action precludes the parties or their privies from relitigating issues that were or could have been raised in that action."). For a more extensive explanation of the different types of and rationales for preclusion, see note 4.

12 D'Arcy v Ketchum, 52 US (11 Howard) 165, 175-76 (1850) (holding that a judgment lacking personal jurisdiction was void and could not form the basis of res judicata); Elliott $v$ Lessees of Peirsol, 26 US (1 Pet) 328 (1828) (finding that a subject matter defect voided a judgment). For a historical analysis of the validity requirement, see Krugman, Note, 87 Yale L J at 165-71 (cited in note 1).

13 See Durfee v Duke, 375 US 106, 113-14 (1963) (examining the history of the doctrine of jurisdictional finality).

14 See id at 111-15 (holding that the determination of a Nebraska court that it had subject matter jurisdiction insulated its judgment on the merits from collateral attack in a Missouri court on grounds that the Nebraska court lacked such jurisdiction). See also Baldwin v Iowa State Traveling Men's Association, 283 US 522, 525-26 (1931) (noting that at least where the defendant appears in the prior court to challenge personal jurisdiction, the resulting judgment cannot be collaterally challenged on validity grounds).

15 See Durfee, 375 US at 116 (noting that the prior Nebraska court had already found its subject matter jurisdiction). The term "rendering court" refers to those courts that enter the final 
court never addressed the question of subject matter jurisdiction, and vertical appeals have been exhausted, then any objection to subject matter jurisdiction has been waived. ${ }^{16}$ The rules of jurisdictional finality, at least among state courts, are of constitutional importance." In the end, the "validity" of a judgment on subject matter jurisdiction grounds ${ }^{18}$ is conferred to the sole discretion of the rendering court. Second, dismissals for lack of jurisdiction are not "on the merits" and are, therefore, not res judicata or claim preclusive. ${ }^{19}$ In other words, a dismissal for lack of jurisdiction cannot preclude the plaintiff from bringing his cause of action in another court.

However, a jurisdictional dismissal can be the basis for issue preclusion in that other court. In general, a jurisdictional dismissal precludes relitigation of the "precise issue of the jurisdiction" of the dismissing court. ${ }^{20}$ This issue preclusive effect prevents the inefficient relitigation of a common jurisdictional question within a judicial system. For example, a plaintiff is clearly precluded from relitigating the existence of federal subject matter jurisdiction in a federal district court if her case had previously been dismissed by another federal court. ${ }^{21}$ In

judgment to be used to preclude litigation of claims or issues in subsequent actions. The "rendering court," in this sense, would include not only the trial court in the first action, but also courts deciding direct appeals from the decision of the trial court.

16 Chicot County Drainage District v Baxter State Bank, 308 US 371, 375-76 (1940) (permitting res judicata even where jurisdictional issues were not raised, much less decided, and a finding of jurisdiction was clearly erroneous). This is true notwithstanding that subject matter jurisdiction can be raised at any time during the proceedings, even sua sponte. See, for example, Frey$\operatorname{tag} v$ CIR, 501 US 868, 896-97 (1991). The ability of courts to raise subject matter jurisdiction sua sponte reinforces the legal presumption that the rendering court has found its own subject matter jurisdiction, as the court may not rely exclusively on the arguments of the parties in this area.

17 See Durfee, 375 US at 109, 111 (interpreting the Full Faith and Credit Clause, US Const Art IV, $\S 3$, to require that the rendering court have plenary, collaterally unreviewable authority to determine its own jurisdiction). These rules are similarly applicable to the effects of judgments rendered by federal courts in state courts through similar interpretations of the Full Faith and Credit Act, 28 USC $\$ 1738$ (1994), and the Supremacy Clause of Art VI, § 1. See notes 49-51.

18 This calculus is slightly different for personal jurisdiction defects. A default judgment, rendered without personal jurisdiction, is not "valid" notwithstanding the decision of the rendering court. That is, a default judgment may be collaterally challenged on personal jurisdiction grounds. See Insurance Corp of Ireland, Ltd v Compaignie des Bauxites de Guinee, 456 US 694, 706 (1982) (ruling that asserting judicial power in the form of a default judgment violates due process until the court establishes personal jurisdiction). However, when a defendant appears, and either loses or does not raise a personal jurisdiction objection, personal jurisdiction cannot be collaterally challenged. See id.

19 FRCP 41(b) (noting that a jurisdictional dismissal is not an adjudication "on the merits"); Restatement (Second) of Judgments $\S 20(1)($ a) (providing that jurisdictional dismissals are not claim preclusive).

20 Winters v Diamond Shamrock Chemical Co, 149 F3d 387, 395 \& n 10 (5th Cir 1998) (forbidding a party from asserting offensive, non-mutual collateral estoppel based on a subject matter jurisdiction dismissal); North Georgia Electric Membership Corp v City of Calhoun, 989 F2d 429, 433 (11th Cir 1993). See also Part III.B (discussing the "precise issue of jurisdiction" tests).

21 See, for example, Oglala Sioux Tribe of Pine Ridge Indian Reservation v Homestake Mining Co,722 F2d 1407, 1411 (8th Cir 1983) (noting that federal dismissal for lack of subject matter 
the case of federal subject matter jurisdiction, the intersystem (that is, between federal and state courts) issue preclusive effect of such dismissals was rarely relevant. If a federal court dismisses a cause of action for lack of subject matter jurisdiction, that dismissal does not preclude the claim from being filed in an appropriate state court, as the dismissal is not "on the merits." the relitigation of federal subject matter jurisdiction in state court, the jurisdiction of the federal court is simply not relevant in a state court, facing entirely different subject matter jurisdiction questions. ${ }^{23}$

Thus, the preclusive effect of federal court orders absent subject matter jurisdiction before Ruhrgas was narrow. If the federal court explicitly found that it did not have subject matter jurisdiction, and accordingly dismissed the cause of action, any preclusive effect of that dismissal in subsequent litigation was limited to the precise issue of jurisdiction. $^{24}$

\section{B. Ruhrgas and Explicitly Deferring Questions of Subject Matter Jurisdiction}

The Supreme Court in Ruhrgas permitted a federal court, under certain circumstances, to dismiss an action for want of personal jurisdiction before deciding whether it had subject matter jurisdiction. ${ }^{25}$ In doing so, the Court enabled lower federal courts explicitly to defer the question of their subject matter jurisdiction and finally resolve the controversy on other grounds, at least under certain circumstances. The action of explicitly deferring subject matter jurisdiction is not a case covered by previously existing rules of jurisdictional finality, which alternatively presume that the court has found its subject matter jurisdiction when the court acts on other grounds ${ }^{26}$ or attach issue

jurisdiction precludes relitigation of subject matter jurisdiction in another federal court). See also Holloway $v$ Brush, $220 \mathrm{F3d} 767,778$ (6th Cir 2000) (en banc) (distinguishing the lack of claim preclusion attached to jurisdictional dismissals).

22 Moreover, questions of jurisdictional finality are not implicated. Here, any resolution of the merits before the dismissal is not "valid" on the very terms of the rendering court's disposition of the case. See note 19 .

23 State courts are courts of "general, not limited," subject matter jurisdiction. See Bender $v$ Williamsport Area School Dist, 475 US 534, 541 (1986). State courts do not face the diversity or federal question limits on subject matter jurisdiction. Accordingly, state courts may hear cases of federal or state law. See Lockhard v Freewell, 506 US 364, 375-76 (1993) (discussing this incident of general subject matter jurisdiction). Occasionally, federal subject matter jurisdiction will be exclusive, thus limiting the general subject matter jurisdiction of state courts. See Matsushita Electric Industrial Co v Epstein, 516 US 367, 383-86 (1996) (discussing exclusive federal jurisdiction over some actions under the Securities Exchange Act of 1934). However, a federal jurisdictional dismissal, and accordingly the question of its preclusive effect, will never arise in such a case since the federal court will retain jurisdiction and dispose of the case on the merits.

24 See notes 124-25.

25526 US at 528.

26 See Part I.A. 
preclusive effect to the court's denial of its jurisdiction. Thus, it is an open question whether a federal court's dismissal of a case for lack of personal jurisdiction, while explicitly holding the question of its subject matter jurisdiction in abeyance, precludes the relitigation of personal jurisdiction in other courts.

Most importantly, the Court in Ruhrgas raises the possibility of jurisdictional finality away from its core purpose of preventing inefficient relitigation among courts in a single judicial system. ${ }^{27}$ Prior to Ruhrgas, federal courts were permitted to decide some questions, such as class certification, prior to determining their subject matter jurisdiction. ${ }^{28}$ However, none of these issues had any currency outside federal courts, and therefore, any potential preclusive effect in state litigation. ${ }^{29}$ For example, while a federal court's dismissal of a class action for failure to meet the requirements of Rule 23 would be issue preclusive, the issue of a class action's conformity with federal class action rules would generally not arise in state court because state class actions would be governed by state class action rules. ${ }^{30}$

In contrast, the relevance of personal jurisdiction is not limited to federal court. The question of personal jurisdiction is identical in a state court and a federal district court sitting in that state: whether the state's long-arm statute authorizes personal jurisdiction over the de-

27 See Baldwin v Iowa State Traveling Men's Association, 283 US 522, 525-26 (1931) (discussing the inefficiencies of permitting relitigation of jurisdiction among federal courts).

28 See Amchem Products, Inc v Windsor, 521 US 591, 612 (1997) (holding that resolution of class certification issues is "logically antecedent to" Article III questions as their outcome may depend on the content of the class certified). See also Arizonans for Official English $v$ Arizona, 520 US 43, 66-67 (1997) (permitting dismissal of the case for mootness even amidst significant standing questions); Willy $v$ Coastal Corp, 503 US 131, 137-40 (1992) (allowing the imposition of FRCP 11 sanctions prior to finding subject matter jurisdiction); Marathon Oil Co $v$ AG Ruhrgas, 145 F3d 211, 221 (5th Cir 1998) (en banc) (noting that courts have long held trials, assessed costs, and conducted discovery before finding subject matter jurisdiction).

29 See, for example, In re General Motors Corp Pick-up Truck Fuel Tank Products Liability Litigation, 134 F3d 133, 145-46 (3d Cir 1997) (suggesting that dismissal for lack of a certifiable class, while not jurisdictional, was not sufficiently final to be res judicata). Similarly, mootness, resting on the case or controversy requirement of Article III, does not limit the judicial power of state courts. See US Const, Art III, $§ 1$ (limiting the judicial power of federal courts); DeFunis $v$ Odegaard, 416 US 312, 316 (1974) (explaining that the mootness restriction on federal courts is a function of the "case or controversy" requirement of Article III of the US Constitution); George Brown, Binding Advisory Opinions: A Federal Courts Perspective on the State School Finance Decisions, 35 BC L Rev 543 (1994) (discussing state court power to render advisory opinions, unfettered by Article III).

30 Admittedly, if the federal and state class action rules were similar, a federal court's dismissal on Rule 23 grounds might be quite persuasive. The federal dismissal, however, would not be issue preclusive because the legal questions would be technically different. See General Motors, 134 F3d at 146 (holding that FRCP 23 decisions were not preclusive of class certification under Louisiana class action rules); J.R. Clearwater Inc v Ashland Chemical Co, 93 F3d 176, 180 (5th Cir 1996) (noting that federalism counsels against permitting a federal judgment regarding federal class action rules to preclude litigation under state class action rules, even when state class action rules mimicked the language of FRCP 23). 
fendant and whether the exercise of personal jurisdiction would be within the limits of the Due Process Clause of the Fourteenth Amendment. ${ }^{31}$ By permitting the dismissal of cases for want of personal jurisdiction while explicitly not deciding federal subject matter jurisdiction, the Court has permitted, for the first time, a final action by a federal court on an issue with a state law analogue in the face of deferred questions over its subject matter jurisdiction.

The Court suggests that its permission to decide personal jurisdiction first is limited to cases in which the personal jurisdiction issue is easier than a complex subject matter jurisdiction problem. ${ }^{32}$ If the power to dismiss were truly limited to cases in which the personal jurisdiction question were clear, then the potential of precluding state determinations of personal jurisdiction might be of little concern. For easy questions, the state court would arrive at the same conclusion, precluded or not.

There are two reasons, however, why even the Court's limitation does not practically eliminate the preclusion problem. First, what appears to be a clear lack of personal jurisdiction to a federal judge may appear more complex to a state judge who might be more aggressive in her exercise of personal jurisdiction. ${ }^{33}$ Second, the Supreme Court did not say that the personal jurisdiction question need be easy, rather just easier than a very complex subject matter jurisdiction issue, therefore leaving a wide range of otherwise difficult personal jurisdiction questions for federal courts to decide first. ${ }^{34}$

31 See FRCP 4(k)(1)(A) (allowing personal jurisdiction when the defendant "could be subjected to the jurisdiction of a court of general jurisdiction in the state in which the district court is located"). As a constitutional matter, federal district courts are bound only by the limits on personal jurisdiction in the Fifth Amendment Due Process Clause. US Const Amend V. See also note 134. However, since federal courts must borrow the state jurisdictional framework, see FRCP $4(k)(1)(A)$, the federal court will decide the personal jurisdiction question according to the limits of the Fourteenth Amendment.

32 See Ruhrgas, 526 US at 587-88. We might be concerned that this standard of comparative difficulty shows little promise for effectively cabining a district court's discretion in ordering jurisdictional dispositions.

33 See Michael E. Solimine, The Quiet Revolution in Personal Jurisdiction, 73 Tulane L Rev 1, 51-53 (1998) (surveying systematically courts' treatment of personal jurisdiction, noting that state courts find personal jurisdiction more often than federal courts, and arguing that this is, in part, due to state courts' greater sensitivity to local interests).

34 See Ruhrgas; 526 US at 577-78 (noting that the central question is whether "federal district courts have discretion to avoid a difficult question of subject matter jurisdiction when the absence of personal jurisdiction is the surer ground") (emphasis added). The Court did suggest that district courts may be limited in this discretion when the personal jurisdiction question presents "complex state-law questions." Id at 582. The Court did not suggest how complex those state law questions must be to trigger this limitation amidst a difficult subject matter jurisdiction issue. Moreover, even this limitation leaves within this discretion a wide range of determinations regarding federal limitations on personal jurisdiction, which would otherwise be left to the discretion of state courts absent subject matter jurisdiction. See notes 117-21 (discussing how questions of federal law are left exclusively to state courts absent federal subject matter jurisdiction). 


\section{The Reasoning of Ruhrgas and the "Precise Issue of Jurisdiction"}

While Ruhrgas permitted federal courts to decide personal jurisdiction first, the Court did not directly face the question of whether that determination would be preclusive in state court. The Court, however, did address the possibility of issue preclusion absent subject matter jurisdiction in the course of its argument for permitting the consideration of personal jurisdiction first. ${ }^{35}$ Marathon Oil had argued that federalism demands that a federal court abstain from dispositive action on personal jurisdiction grounds absent certainty regarding its subject matter jurisdiction. ${ }^{36}$ The premise of this argument was that such a dismissal could preclude a state court's independent determination of its own personal jurisdiction. ${ }^{37}$ According to the Court, the potential for issue preclusion may not be limited to dismissals for lack of personal jurisdiction. Dismissals for lack of subject matter jurisdiction, the Court suggested, could also preclude state adjudication of certain issues on the merits. ${ }^{38}$ The Court offered an example of a federal plaintiff who failed to meet the amount in controversy requirement for diversity jurisdiction. ${ }^{39}$ If (1) a complaint alleged that the defendant breached a contract for which the plaintiff was entitled to fifty thousand dollars in compensatory damages and one million dollars in punitive damages; and (2) the court held that as a matter of state law, punitive damages were not available for breach of contract and that therefore there was no diversity jurisdiction; then (3) the plaintiff "may" be precluded from seeking punitive damages in state court."

The Court's suggestion here either elides or displaces the traditional rule that a federal court's dismissal for lack of subject matter jurisdiction is issue preclusive only with regard to the "precise issue of jurisdiction." The Court's amount in controversy example suggests that the issue preclusive effect of such dismissals could extend to issues of fact and law on the merits which were "actually litigated and

35 See Ruhrgas, 526 US at 585-86.

36 Id at 585. See also Brief for Respondents 12-13, Ruhrgas AGv Marathon Oil Co, No 98470 (filed Feb 24, 1999) (available on Lexis at 1998 U.S. Briefs 470). It is clear that a federal district court's dismissal for lack of personal jurisdiction has an issue preclusive effect when the court's subject matter jurisdiction is not at issue. See Baldwin v Iowa State Traveling Men's Association, 283 US 522, 524-26 (1931) (holding that a decision on personal jurisdiction made by a federal court in Missouri precluded relitigation of the personal jurisdiction issue by a federal court in Iowa).

37 Ruhrgas, 526 US at 585.

38 Id at 585-86.

39 See 28 USC $\$ 1332$ (a) (1994 \& Supp 2000) (requiring that the "matter in controversy" exceed seventy-five thousand dollars when the only basis for jurisdiction is diversity of citizenship).

41 See text accompanying notes $123-27$. 
necessarily decided" to reach the jurisdictional question. ${ }^{42}$ However, if the issue preclusive effect of jurisdictional dismissals extends to intermediate questions on the merits, then the "precision" requirement for jurisdictional preclusion ${ }^{43}$ appears to reflect only the general rules for collateral estoppel.

The Ruhrgas Court's discussion of those determinations to which an issue preclusive effect may be attached in the course of a jurisdictional dismissal raises significant questions about what a defendant really has when a federal court dismisses the case against him on jurisdictional grounds. When combined with the limited authorization to decide personal jurisdiction while explicitly deferring the determination of subject matter jurisdiction, the Court lays the foundation for a broad federal court power to preclude relitigation in state court amidst explicit uncertainty regarding whether subject matter jurisdiction exists. However, since the controversy in Ruhrgas itself was not focused on preclusion, the questions concerning the preclusive effect of federal court judgments without subject matter jurisdiction remain open. ${ }^{44}$ Given the uncertain preclusive effects of federal court decisions deferring or finding a lack of subject matter jurisdiction, Part II proceeds to argue that the federal courts have the power to address this confusion by adopting rules governing the preclusive effects of their own decisions.

\section{The Federal Power to Develop Preclusion Rules}

Generally, the preclusive effect of a judgment is governed by the res judicata and collateral estoppel rules of the court rendering the judgment. ${ }^{45}$ Applied to federal Ruhrgas or subject matter jurisdiction

42 Although the Court does not use this terminology, its conclusion could rest on the general test for issue preclusion from judgments on the merits. See generally and most famously, Cromwell v County of Sac, 94 US 351, 353 (1876) ("In all cases ... where it is sought to apply the estoppel of a judgment rendered upon one cause of action to matters arising in a suit upon a different cause of action, the inquiry must always be as to the point or question actually litigated and determined in the original action."). See also Baker v General Motors Corp, 522 US 222, 233 \& $\mathbf{n} 5$ (1998) (discussing the test for determining which issues are precluded by a judgment); Restatement (Second) of Judgments $\S 27$ (providing for preclusion of an issue of fact or law that "is actually litigated" and where the determination of such issue "is essential to the judgment"). In this example, the availability of punitive damages would be "necessarily decided" as essential to finding that the claim fell below the jurisdictional amount.

43 See notes 123-25 and accompanying text.

44 Even if the Court were firm in the predicted result of its example, a relatively uncontroversial application of the holding/dicta distinction would keep the question of preclusive effect open. However, the Court's hedging and uncertain language regarding the proper issue preclusive effect suggest more strongly that this question is still unsettled. See Ruhrgas, 526 US at 58586.

45 See Migra v Warren City Sch Dist Bd of Education, 465 US 75, 81 (1984) ("It is now settled that a federal court must give to a state court judgment the same preclusive effect as would be given that judgment under the law of the state in which the judgment was rendered."); Allen v 
dismissals, the preclusive effect of such dismissals would appear to be governed by federal preclusion rules, since a federal court rendered the judgment. However, to say that the relevant preclusion rules are federal says little about the content of those rules. The preclusion rules of a federal court may merely be the preclusion rules of the state in which that court sits.

Many federal courts determining the preclusive effects of federal judgments appear to overlook the choice-of-law question. At the heart of this question is the Erie doctrine, which holds that federal courts, in the absence of a constitutional or statutory basis for decision, must apply state law. ${ }^{47}$ The resolution of the choice-of-law question may independently resolve the question of what preclusive effect attaches to federal subject matter jurisdiction and Ruhrgas dismissals. If the Erie doctrine deprives federal courts of the power to develop their own preclusion rules and state law applies, then state courts may develop rules to protect their own federalism interests. ${ }^{48}$ This Comment argues, however, that federal courts have the authority to develop federal rules to govern the preclusive effect of Ruhrgas and subject matter jurisdiction dismissals. First, this Comment asserts that federal law governs the preclusive effect of all federal judgments. Second, and in the alternative, this Comment claims that Rule 41(b) of the Federal Rules of Civil Procedure gives federal courts the power at least to determine preclusion rules for jurisdictional dismissals.

\section{A. Federal Courts Have a General Power to Determine the Rules Governing the Preclusive Effect of Federal Judgments}

The Erie question with regard to governing rules of preclusion has been divided between cases resting on federal question or diversity jurisdiction. For federal question cases, it is fairly well settled that federal courts are authorized to develop their own rules of preclusion. $^{49}$ These federal preclusion rules govern the preclusive effect of

McCurry, 449 US 90, 96 (1980) (discussing preclusive effect given to state court judgment using state rules). See also Restatement (Second) of Conflicts of Law § 95 (1971) (noting the general rule that the law of the court rendering the judgment determines the scope of the issues precluded by that judgment); Restatement (Second) of Judgments $\S 28 \mathrm{cmt}$ e ("In many such cases [where a subsequent case is brought in a different jurisdiction] the Full Faith \& Credit Clause or the Supremacy Clause of the United States Constitution, or federal statutes or rules of decision, may require that preclusive effect be given to the first judgment.").

46 See, for example, Winters v Diamond Shamrock Chemical Co, 149 F3d 387, 395 (5th Cir 1998) (looking to federal decisions from several circuits to determine preclusive effect of a judgment).

47 Erie Railroad Co v Tompkins, 304 US 64, 78 (1938).

48 But see note 67.

49 See Blonder-Tongue Laboratories, Inc v University of Illinois Foundation, 402 US 313, 324 \& $n 12$ (1971) (holding that the res judicata effects of a federal judgment in patent infringement, which presents federal question jurisdiction, are governed by federal law in a later federal 
federal question judgments in state, as well as federal, courts. ${ }^{50}$ The Supreme Court has interpreted the Full Faith and Credit Act ${ }^{51}$ as statutory authority for federal courts to develop their own rules of preclusion. ${ }^{52}$ Other courts and commentators have attributed the power of federal courts to develop preclusion rules for at least federal question judgments to their "judicial power" to decide "cases and controversies" under Article III."

None of these justifications is easily cabined to federal question cases. Since the Full Faith and Credit Act is cast exclusively in terms of the effect of state court judgments, ${ }^{54}$ it cannot distinguish between diversity and federal question cases. Similarly, Article III judicial power over "cases or controversies" extends to diversity cases just as much as federal question cases. ${ }^{55}$ Moreover, the Erie doctrine is not limited to cases in which jurisdiction is based solely on diversity. ${ }^{56}$ Federal courts do not have a greater power to develop federal common law in cases based on federal question jurisdiction. ${ }^{57}$ Accordingly, the Rules of Decision Act, ${ }^{58}$ the statutory instantiation of the Erie doctrine, provides

court proceeding); Heiser $v$ Woodruff, 327 US 726, 733 (1946) (holding, consistent with Erie, that where a federal judgment, for which federal question jurisdiction governed, was sought to be enforced in a later bankruptcy proceeding, federal preclusion rules were applicable).

50 See Stoll v Gottlieb, 305 US 165, 169-71 (1938) (overturning the application of Illinois rules of preclusion by the Illinois Supreme Court to a decree rendered in federal court).

5128 USC \& 1738 (1994).

52 See Stoll, 305 US at 171 (distinguishing the Full Faith and Credit Clause, US Const Art IV, $\S 1$, which does not apply to federal court judgments, from the coverage of the Full Faith and Credit Act).

53 See, for example, Ronan E. Degnan, Federalized Res Judicata, 85 Yale L J 741, 768-69 (1976) (arguing that the effect of a judgment rendered by any court within the United States or judicial proceedings in any other jurisdiction is a matter of federal law).

54 See Full Faith and Credit Act, 28 USC $\$ 1738$ ("The records and judicial proceedings of any court of any such State ... shall have the same full faith and credit in every court within the United States ... as they have by law or usage in the courts of such State ... from which they are taken.") (emphasis added).

55 See US Const Art III, $\& 2$ ("The judicial power shall extend to all Caşes, in Law and Equity, arising under this Constitution, the Laws of the United States, and Treaties ... to Controversies ... between citizens of different states.").

56 See Charles Alan Wright and Kenneth W. Graham, Jr., 21 Federal Practice and Procedure $\$ 5135$ at 659 (West 1977). It is true that some courts often speak as if Erie were only relevant in diversity cases. See, for example, Bass v First Pacific Networks, Inc, 219 F3d 1052, 1055-56 (9th Cir 2000). This is understandable because determining governing substantive law is most critical in diversity cases with no federal law characterizing the cause of action.

57 See Stewart Organization, Inc v Ricoh Corp, 487 US 22, 32 (1988) (holding that the mere fact that the plaintiff's cause of action was characterized by federal antitrust law, triggering federal question jurisdiction, did not empower federal courts to make common law in determining the validity of a forum selection clause).

58 See 28 USC $\$ 1652$ (1994) ("The laws of the several states, except where the Constitution or treaties of the United States or Acts of Congress otherwise require or provide, shall be regarded as rules of decision in civil actions in the courts of the United States, in cases where they apply."). See also Stewart Organization, 487 US at 39 (Scalia dissenting) (The "Rules of Decision Act 'itself neither contains nor suggests ... a distinction' between federal-question cases 
that state law shall provide the rules of decision in the absence of contrary federal statutory or constitutional law, "in all civil actions," not just those based solely on diversity.

Unsurprisingly, the Supreme Court's decision in Dupasseur $v$ Rochereau, ${ }^{\infty 0}$ that the preclusion rules of the state in which the rendering federal court sits govern the preclusive effect of judgments in diversity cases, predates Erie. Since Erie, circuit courts of appeals have sharply split on whether federal or state preclusion law governs diversity judgments. ${ }^{61}$ The reasoning behind the federal preclusion rules for federal question judgments renders the distinction of diversity cases highly unstable.

\section{B. Federal Rule of Civil Procedure 41(b) Gives Federal Courts the Power to Develop Preclusion Rules}

The possible distinction between diversity and federal question cases does little to resolve the source of governing preclusion law in the two instances that this Comment addresses: where cases have been dismissed for lack of subject matter jurisdiction or a finding of jurisdiction has been explicitly deferred. In these cases, there is no (determined) basis for subject matter jurisdiction.

Where a case has been dismissed for lack of subject matter jurisdiction, or on other grounds while deferring subject matter jurisdiction, courts are on firm ground in developing federal preclusion rules. Rule 41(b) of the Federal Rules of Civil Procedure directly addresses the preclusive effect of a dismissal before a full trial on the merits: unless the court otherwise specifies, a dismissal is presumed to be an adjudication on the merits except for a dismissal for lack of jurisdiction, improper venue, or failure to join a party under Rule $19 .^{63}$ While

and diversity cases.").

5928 USC \& 1652.

6088 US 130, 135 (1874) (holding that state preclusion law governed federal judgment based on alienage jurisdiction).

61 Compare Henderson v United States Fidelity and Guaranty Co, 695 F2d 109, 112 \& n 3 (5th Cir 1983) (applying federal issue preclusion rules to a diversity judgment), and Semtek International, Inc $v$ Lockheed Martin Corp, 736 A2d 1104,1110-12 (Md Ct App 1999) (finding that federal preclusion rules do govern judgments of federal courts even when jurisdiction is based on diversity), cert granted 120 S Ct 2715 (2000), with Iowa Elec Light and Power Co v Mobile Aerial Towers, Inc, 723 F2d 50, 52 (8th Cir 1983) (refusing to permit non-mutual offensive collateral estoppel, permitted by federal preclusion rules, because the state in which the rendering federal court sat in diversity did not permit it).

62 Accordingly, the Restatement (Second) of Judgments $\$ 87$ has ignored the distinction: "Federal law determines the effects under the rules of res judicata of a judgment of a federal court." For a vigorous argument that federal rules apply even to diversity judgments, see Degnan, 85 Yale L J at 765-73 (cited in note 53). But see Stephen B. Burbank, Interjurisdictional Preclusion, Full Faith and Credit and Federal Common Law: A General Approach, 71 Cornell L Rev $733,778-97$ (1986) (arguing that state preclusion law ought to apply to diversity judgments).

63 FRCP 41(b). 
Rule 41(b) does not specify the preclusive effect of jurisdictional dismissals, federal courts proceed with stronger authority under Erie in developing procedural common law in the shadow of a federal rule of civil procedure. ${ }^{64}$ Indeed, several circuits have held that Rule 41(b) forecloses the application of state preclusion law for dismissals short of a judgment after a trial on the merits. ${ }^{65}$ The grounds for dismissal which Rule 41(b) specifically excludes from effectively becoming an adjudication on the merits are uniquely federal. ${ }^{66}$ Federal courts would be much better situated to develop nuanced rules of preclusion which address both the unique procedural posture and substantive concerns regarding federal jurisdictional dismissals."

Thus, federal courts should have the power to develop federalism-sensitive preclusion rules for two alternative reasons: (1) federal courts should have the power to develop preclusion rules for all judgments that they render, notwithstanding the jurisdiction on which the judgments rest; and (2) even if federal preclusion rules do not govern federal judgments based on diversity jurisdiction, Rule 41(b) suggests that federal courts have particular statutory authorization for developing preclusion rules for jurisdictional dismissals.

\section{PREClusive AbSTENTION AMIDST UNCERTAINTY REGARDING SUBJECT MATTER JURISDICTION}

Federal courts should develop rules of preclusion which are sensitive to the unique role subject matter jurisdiction plays as sentry for judicial, or "adjudicatory," federalism. Crucial to the framers' design of the judicial power of federal courts in Article III was the idea that state courts should have exclusive original jurisdiction over controversies of both federal and state law except where Congress has specifi-

64 See, for example, Hanna v Plumer, 380 US 460, 473-74 (1965) (holding that federal courts in diversity actions should apply the federal rules of civil procedure, even when they conflict with state substantive law).

65 See, for example, PRC Harris, Inc v Boeing Co, 700 F2d 894, 896-97 (2d Cir 1983) (applying FRCP 41(b) where claims were barred by the statute of limitations).

66 For example, state courts dismiss on forum non conveniens grounds rather than for improper venue concerns under 28 USC $\S 1391$. State courts, which often have general subject matter jurisdiction, rarely deal with subject matter jurisdiction dismissals. For a notable exception, see Durfee v Duke, 375 US 106, 107-08 (1963) (collateral challenge to state court's subject matter jurisdiction over suit to quiet title to land which was (arguably) not in the state of the rendering court).

67 It is possible that if state preclusion rules were to govern, then states could protect their own federalism interests to the extent desired by denying a significant preclusive effect to $R$ uhrgas and subject matter jurisdiction dismissals. However, it is not clear that state courts could constitutionally discriminate against jurisdictional dismissals by federal as opposed to state courts. See Testa $v$ Katt, 330 US 386, 389 (1947) (noting that state courts cannot develop procedural rules which discriminate against federal law due to the Supremacy Clause, US Const Art VI, § 1). Thus, the capability of state courts to develop federalism-sensitive preclusion rules is limited. 
cally granted federal courts original jurisdiction within Article III limits. $^{68}$ State courts' exclusive jurisdiction is not violated except where federal courts are able to preclude an original adjudication in state court. $^{69}$ The essence of limited subject matter jurisdiction is the limited preclusive power of federal courts. Limiting the preclusive power of federal courts should serve as the last line of defense for the state adjudicatory interests embodied in the Madisonian Compromise.

In the case of Ruhrgas dismissals, preclusion should be limited to the relitigation of personal jurisdiction over the defendant in federal courts situated in the subject state, not extended to state courts. With regard to dismissals for lack of subject matter jurisdiction, preclusion should be limited to the "precise" issue of jurisdiction and not extended to intermediate findings of fact and law on the merits. Developing these narrowly tailored preclusion rules is crucial in the context of Ruhrgas and subject matter jurisdiction dismissals because it is the only result that is consistent with: (1) both Ruhrgas and the core of federal courts' limited subject matter jurisdiction; (2) the unique relationship between the "precise issue of jurisdiction" and a federal court's limited "jurisdiction to determine its own jurisdiction"; and (3) the truncated procedural process by which jurisdictional decisions are generally made.

\section{A. The Nature of Limited Federal Subject Matter Jurisdiction and
1. The heart of the Madisonian Compromise and adjudicatory federalism. the Reserved Adjudicatory Power of State Courts after Ruhrgas

The most recent federalism decisions have protected state interests in autonomous prescription rather than adjudication. ${ }^{71}$ In terms of "prescriptive federalism," that is, the power to legislate, federal courts protect state interests not only with regard to constitutional limits, but also congressional limits. ${ }^{72}$ If the Constitution does not permit Congress to exercise prescriptive power, courts invalidate statutes and allow states independently to legislate. ${ }^{73}$ If the Constitution permits fed-

68 See note 79.

69 If a federal judgment is not preclusive on an issue, a state court may have it relitigated and decide it independently of federal interference.

70 See Part III.A.1.

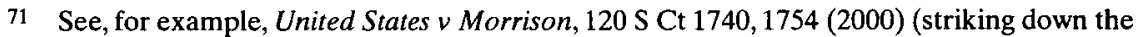
Violence Against Women Act as in excess of Congress's power under the Commerce Clause and Section Five of the Fourteenth Amendment); United States v Lopez, 514 US 549, 565-67 (1995) (invalidating federal law proscribing the possession of guns near schools as beyond Congress's power under the Commerce Clause).

72 See notes 73,77-80.

73 See, for example, Lopez, 514 US at 567 (permitting states to determine criminal penalities for possession of guns near schools). 
eral prescription, but Congress has not acted, federal courts protect state legislative autonomy by applying state law. ${ }^{74}$ If autonomous prescription were the extent of state federalism interests, then state interests would not be violated by federal courts finally deciding legal and factual questions without jurisdiction as long as federal courts applied state law."

The framers, however, conceived of a more robust, adjudicatory federalism. A limited federal government was perceived to preserve not only the interests of state legislatures in autonomous prescription through isolated delegations of legislative power, ${ }^{76}$ but also the interests of state courts in autonomous adjudication absent a delegated power to adjudicate. ${ }^{7 n}$ In 1789 , and until 1938 and the Erie doctrine, the power to adjudicate was as important as the power to legislate because courts, both state and federal, possessed broad common law powers to develop substantive law without any express authorization from their respective legislative branches. ${ }^{78}$ To protect this important state interest in independent adjudication, the framers created federal courts of limited subject matter jurisdiction. Inferior federal courts have subject matter jurisdiction if and only if expressly authorized by congressional statute, and such authorization is within the limits on subject matter jurisdiction in Article III. ${ }^{79}$

74 See Erie Railroad Co v Tompkins, 304 US 64, 78 (1938) (requiring federal courts to apply state law even when Congress is empowered, but has not chosen, to legislate in an area).

75 Of course, this would turn on whether the federal courts applied state law correctly. The Supreme Court has been concerned that the incorrect application of state law, especially absent the relevant interpretation of state law by a state court, jeopardizes prescriptive federalism. Accordingly, the Supreme Court has encouraged federal courts to certify questions of state law, where the risk of error is extremely high, to state courts for resolution. See, for example, Fiore $v$ White, 120 S Ct 469, 473 (1999) (certifying a question to the Pennsylvania Supreme Court regarding the interpretation of an ambiguous state statute); Clay $v$ Sun Insurance Office, Ltd, 363 US 207,212 (1960) ("[W]e have frequently deemed it appropriate ... to secure an authoritative state court's determination of an unresolved question of its local law."). See also Part III.A.2.

76 See US Const Art I, § 8; US Const Amend X. See Gordon S. Wood, The Creation of the American Republic, 1776-1787 453-63 (UNC 1998) (discussing the growing importance of state judicial power prior to the founding).

77 In some sense, adjudicatory federalism can be conceived as an even broader limitation on Congress because Congress can permit federal courts to hear cases by exercising its prescriptive authority (creating a federal cause of action) and triggering federal question jurisdiction.

78 See, for example, Swift $v$ Tyson, 41 US (16 Peters) 1 (1842) (holding that federal courts could develop their own common law contract rule which expressly contradicted that of the courts of the state in which the transaction occurred). Before Erie, the power independently to adjudicate was effectively the power to prescribe. See Erie, 304 US at 78 ("Except in matters governed by the Federal Constitution or by Acts of Congress, the law to be applied in any case is the law of the State."). Some commentators have opined that this state of affairs has not changed considerably notwithstanding Erie. See John Hart Ely, The Irrepressible Myth of Erie, 87 Harv L Rev 693, 698 (1974); Henry J. Friendly, In Praise of Erie-And of the New Federal Common Law, 39 NYU L Rev 383, 405 (1964).

79 See, for example, Sheldon v Sill, 49 US (8 How) 441, 448-49 (1850) (holding that Congress need not extend federal courts' subject matter jurisdiction up to Article III's limits). Inter- 
These two necessary thresholds for the subject matter jurisdiction of inferior federal courts were a product of what has been called the "Madisonian Compromise" in the Constitutional Convention." The framers were generally agreed on the need for some sort of a federal judiciary. ${ }^{81}$ What divided them was whether the Constitution should establish lower federal courts or only one Supreme Court. ${ }^{82}$ James Madison proposed a reconciliation of these two positions: that the Constitution establish no lower federal courts of its own, but authorize Congress to establish federal courts as needed. ${ }^{83}$ One premise of the Madisonian Compromise was that state courts were perfectly capable of adjudicating issues of both federal and state law in the first instance and that appellate review in the Supreme Court would adequately police federal interests in protecting out-of-state citizens and federal law from the most egregious state misinterpretations. ${ }^{84}$ More fundamental, however, was the belief that state courts had crucially important interests in the independent adjudication of controversies and that such interests should only be preempted by federal courts when necessary to protect federal interests. ${ }^{85}$ Federal subject matter jurisdiction was to be

estingly, it is an open question as to whether Congress may constitutionally confer jurisdiction on the Supreme Court, as opposed to inferior federal courts, short of Article III's limits. Historical practice would indicate that it may draw narrower than constitutional limits on subject matter jurisdiction: the Supreme Court has never had appellate jurisdiction over diversity actions below the jurisdictional amount, see 28 USC $\$ 1332$ (a) (1994). Compare state court actions with appealable questions of federal law, 28 USC $\$ 1257$ (a) (1994). Some, however, have argued that Congress must extend the Supreme Court's appellate jurisdiction over at least all issues involving federal questions and treaties. See, for example, Akhil Reed Amar, A Neo-Federalist View of Article III: Separating the Two Tiers of Federal Jurisdiction, 65 BU L Rev 205, 218-19 (1985) (noting that Article III provides that the judicial power of the United States shall extend to all federal question cases, without similar language when discussing party-status cases).

80 Richard H. Fallon, Jr., Daniel J. Meltzer, and David L. Shapiro, eds, Hart and Wechsler's The Federal Courts and the Federal System 8-9, 294-95 (Foundation 4th ed 1996) (describing how Madison overcame powerful objections to the need of any inferior federal courts by proposing that Congress be vested with the power "to institute" such courts at its discretion). To track the debates over this compromise among the framers, see Max Ferrand, ed, 1 The Records of the Federal Convention of 1787 124-25 (Yale 1911).

81 See Wood, The Creation of the American Republic 453-56 (cited in note 76) (discussing the consensus among the framing generation regarding the need for some type of federal judiciary).

82 See id; Atlantic Coast Line Railroad Co v Brotherhood of Locomotive Engineers, 398 US 281, 285 (1970) (discussing the motivation behind the Madisonian Compromise); Michael Collins, Article III Cases, State Court Duties, and the Madisonian Compromise, 1995 Wis L Rev 39,59 (noting that the principal objections regarding the concurrent competency and independence of federal courts emerged when constitutional creation of lower courts was proposed).

83 See Collins, 1995 Wis L Rev at 59 (cited in note 82) (reviewing the views of some framers on the lack of the necessity of lower federal courts). See also US Const Art III, $\$ 1$ (vesting the judicial power "in such inferior Courts as the Congress may from time to time ordain and establish").

84 See Atlantic Coast, 398 US at 285. See also Collins, 1995 Wis L Rev at 119-24 (cited in note 82) (discussing the potential for state judges to "do federal judicial business").

85 Alexander Hamilton, an ardent federalist, recognized that states had interests in main- 
limited to those cases in which impartial federal adjudication proved needed, as determined by Congress within the limits of Article III. As the limits of explicit reservation to the states of powers not delegated to the states were designed to protect prescriptive federalism, ${ }^{86}$ subject matter jurisdiction defined by Congress within Article III limits was implemented to protect adjudicatory federalism. ${ }^{\mathrm{g}}$

Accordingly, federal courts have repeatedly recognized that grants of subject matter jurisdiction must be narrowly construed in order to avoid the invasion of state interests in independent adjudication. According to the Suprme Court,

The power reserved to the states, under the Constitution, to provide for the determination of controversies in their courts may be restricted only by the action of Congress in conformity to the judiciary sections of the Constitution. Due regard for the rightful independence of state governments, which should actuate federal courts, requires that they scrupulously confine their own jurisdiction to the precise limits which the statute has defined. ${ }^{88}$

Indeed, the principle that state courts have an inviolate interest in independently adjudicating cases and controversies absent federal subject matter jurisdiction has been recently reaffirmed by the $\mathrm{Su}-$ preme Court. ${ }^{89}$ For example, in Alden v Maine, ${ }^{90}$ the Court held that Congress may not abrogate state sovereign immunity in state courts." According to the Court, Congress may not dictate the resolution of adjudications by state courts outside of Article III limits on federal

taining an independent system of courts, similar to state legislative autonomy protected by the constitutionally limited power of Congress. According to Hamilton, a crucial way in which this state judicial autonomy would be protected would be through the retention of state exclusive original jurisdiction, except where Congress may provide for concurrent federal jurisdiction. See Federalist 82 (Hamilton), in Clinton Rossiter, ed, The Federalist Papers 491-93 (Mentor 1961). See also Julius Goebel, Jr., 1 History of the Supreme Court of the United States: Antecedents and Beginnings to 1801 217-23 (Macmillan 1971).

86 See Federalist 32 (Hamilton), in Rossiter, ed, The Federalist Papers at 197-99 (cited in note 85) (discussing the limited powers of Congress and the manner in which state legislative authority is theoretically protected); US Const Amend X (reserving to the states all powers not delegated to the federal government).

87 See note 85 .

88 Healy $v$ Ratta, 292 US 263, 270 (1934) (citations omitted). See also Victory Carriers, Inc $v$ Law, 404 US 202, 212 (1971) (explaining personal injury action, reserved for state law, should not be displaced by a maritime action due to strict interpretation of federal jurisdictional statutes).

89 See Gregory v Ashcroft, 501 US 452, 472 (1990) (holding that the Age Discrimination in Employment Act will not be lightly construed to forbid state mandatory retirement ages for judges given the states' overwhelming interest in a judiciary independent of federal control).

90527 US 706 (1999).

91 Id at 754. Congress sought to abrogate state sovereign immunity in state courts, in large part, because the Court had held that sovereign immunity, as embodied in the Eleventh Amendment, was a limitation on the subject matter jurisdiction of federal courts. See Seminole Tribe of Florida $v$ Florida, 517 US 44, 72-73 (1996). 
subject matter jurisdiction. ${ }^{92}$ On this view, limited federal subject matter jurisdiction is the last, inviolable line of defense against federal infringement of state adjudicatory autonomy. ${ }^{93}$ At its core, therefore, limited federal subject matter jurisdiction protects state adjudication from unwarranted federal interference. Thus, a federal court must be extremely careful not to interfere with an unencumbered state judicial resolution of questions of fact and law absent certainty regarding its subject matter jurisdiction.

2. The unique relationship between intersystem preclusion and adjudicatory federalism.

Of course, the ability of state courts to exercise their original jurisdiction over those cases not within the subject matter jurisdiction of federal courts is only really invaded when the decision of a federal court precludes litigation of an issue of law or fact in a state court. A mere federal court decision on an issue, without preclusive effect in state court, leaves the state interest intact. The Supreme Court, in the context of Younger abstention, has recognized that freedom from federal preclusion lies at the core of judicial federalism. In Younger, ${ }^{94}$ the Supreme Court held that federal courts should abstain from enjoining pending criminal proceedings in state court because of important state interests in enforcing state laws and adjudicating federal defenses." Later, the Court decided that it was not only injunctions that threatened federalism principles.

In Steffel $v$ Thompson, ${ }^{96}$ the Court was faced with the question of whether Younger abstention should be extended to preclude federal courts from making declaratory judgments regarding federal rights at issue in threatened, but not pending, state criminal prosecutions. ${ }^{97}$ In a concurring opinion, Justice Rehnquist engaged the plurality's claim

92 See Alden, 527 US at 743.

93 This is especially clear if sovereign immunity, in essence a state's lack of amenability to suit, is conceived of as it was originally, as a limitation on the adjudicatory authority of courts. See Hans $v$ Louisiana, 134 US 1,18-19 (1890) (holding that state sovereign immunity is a limitation on the subject matter jurisdiction of federal courts). See also US Const Amend XI ("The Judicial power of the United States shall not be construed to extend to any suit ... against one of the United States.").

94 Younger v Harris, 401 US 37 (1971).

95 See id at 43-45 (holding that such injunctions unduly interfere with the legitimate activities of states and violate "Our Federalism" except in certain narrow circumstances). The principle of Younger abstention was later extended to certain civil enforcement proceedings which, while not criminal, were initiated by the state. See, for example, Huffman v Pursue, Ltd, 420 US 592,604 (1975) (applying Younger to a civil abatement proceeding).

96415 US 452 (1974).

97 Id at 454. See also Declaratory Judgment Act, 28 USC \& 2201 (1994) (allowing the federal courts to declare the rights of parties in controversies which would otherwise be in their jurisdiction). 
that a declaratory judgment was less invasive of state interests than an injunction. ${ }^{98}$ According to Justice Rehnquist, if the declaratory judgment were to have a res judicata effect in state court, effectively precluding a relitigation of an issue at the heart of the state prosecution, the effect on federalism would be just as destructive."

The Court's attempted distinction between the invasive effects of injunctions and declaratory judgments isolates whether preclusion alone raises federalism concerns. Justice Rehnquist's suggestion in Steffel that preclusion could critically harm federalism interests ultimately prevailed as the Court eliminated the distinction between declaratory judgments and injunctions for purposes of abstention. ${ }^{100}$

In fact, the debate continues regarding the existence and extent of the preclusive effect of even those declaratory judgments which are permitted by Younger and its progeny on future state prosecutions. Justice Rehnquist has suggested that while the declaratory judgment should be persuasive in state court, it would have no preclusive effect on state prosecutions. ${ }^{101}$

However, withholding preclusion in Younger cases encounters one significant difficulty. The ability to bar such a preclusive effect is in direct tension with the constitutional bar of the "case or controversy" requirement of Article III $^{102}$ against federal courts issuing purely advisory opinions. ${ }^{103}$ If declaratory judgments regarding the

98 Steffel, 415 US at 483.

99 Id at 479 (Rehnquist concurring) (noting that the availability of a "res judicata effect" for a declaratory judgment "would substantially undercut the principle of federalism reaffirmed in Younger v. Harris ... and preserved by this decision today"). Here Justice Rehnquist, while agreeing with Justice Brennan's result, qualifies Justice Brennan's premise that declaratory judgments are less invasive than injunctions. For Rehnquist, declaratory judgments are more protective of federalism if and only if (1) declaratory judgments cannot later be used as the basis for obtaining an injunction, see id at 483-84; and (2) the declaratory judgment does not have a res judicata effect, precluding, even if not enjoining, the state prosecution, see id at $482-83$. Justice Rehnquist, however, does not decide in Steffel whether such a preclusive effect would attach. See id at $479,482 \& \mathrm{n} 3$.

100 Indeed, the Court had earlier barred declaratory judgments in the classic Younger situation, where a prosecution has already been initiated and is pending. See Samuels v Mackell, 401 US 66, 73 (1971). In Samuels, the Court recognized that the "practical impact" on federalism of a declaratory judgment would be virtually the same as an injunction if a preclusive effect attached to that judgment. See id at 72-73. In this sense, Justice Brennan's suggestion in Steffel that declaratory judgments are less invasive of federalism interests was little more than a brief departure from the Court's recognition in Samuels. See notes 96-99 and accompanying text. The smoothing of this distinction comes in later cases permitting injunctions in Steffel cases. See Wooley $v$ Maynard, 430 US 705, 712 (1977) (permitting a permanent injunction against prosecution under a state statute because of the threat of repeated future prosecutions).

101 See Steffel, 415 US at 482 n 3 (Rehnquist concurring). See also Green v Mansour, 474 US $64,72-73 \&$ n 2 (1985) (recognizing the legal uncertainty regarding the preclusive effect of declaratory judgments in quasi-Younger contexts).

102 See US Const Art III, $\$ 2$.

103 See Hayburn's Case, 2 US (2 Dall) 408, 409 (1792) (declining to advise the President on the constitutionality of future executive action). 
constitutionality of applying a state criminal law to certain future conduct had no preclusive effect, then the judgment would finally decide no controversy and be purely advisory. ${ }^{104}$ Indeed, the authority of federal courts to develop preclusion rules has been traced to the constitutional bar against issuing advisory opinions: that the federal court decision must have some preclusive effect to be within the Article III judicial power of federal courts. ${ }^{105}$ Fortunately, limiting the preclusive effect of Ruhrgas and subject matter jurisdiction dismissals would not raise similar Article III concerns. Even if such dismissals had no preclusive effect in state court, they would conclusively and finally end a case's tenure in federal court: for Ruhrgas dismissals on grounds that the federal court had no personal jurisdiction, and for subject matter dismissals on grounds that federal courts cannot entertain the suit. These intrasystem preclusive effects would make these dismissals more than just advisory opinions.

At the heart of Younger is a claim that the adjudication of some disputes, even when they involve federal rights, is exclusively within the judicial power of the states. ${ }^{106}$ When there is a lack of subject matter jurisdiction in a case, the judgment of Congress and, with regard to Article III limits on subject matter jurisdiction, the framers, is that such cases should be exclusively within state control..$^{107}$ If the damage of preclusion is enough in the Younger context to violate principles of federalism, it is no less severe when subject matter jurisdiction is uncertain.

This analogy between Younger-protected state interests and those damaged by preclusion through Ruhrgas and subject matter dismissals should be viewed with some caution. Arguably, state interests are far more important in Younger situations because it is the state which has made the deliberate effort to initiate judicial proceedings, consciously selecting out those state law concerns most important to the state. ${ }^{108}$ In

104 This is a problem for the Declaratory Judgment Act. The rule against advisory opinions is constitutional and cannot be abrogated by statute. See Skelly Oil Co v Phillips Petroleum Co, 339 US 667, 671-72 (1950) (explaining that the Declaratory Judgment Act does not and cannot authorize federal courts to issue advisory opinions). The Court seemed to recognize this dilemma in the abstention context. See Green, 474 US at 73 n 2 ("If, of course, petitioners would make no claim that the federal declaratory judgment was res judicata in later commenced state proceedings, the declaratory judgment would serve no purpose whatever in resolving the remaining dispute between the parties, and is unavailable for that reason.").

105 For a persuasive argument that this minimum Article III requirement of some preclusive effect meets the claim that declaratory judgments regarding state criminal law need not be preclusive, see David L. Shapiro, State Courts and Federal Declaratory Judgments, 74 Nw U L Rev 759,764 (1979).

106 See 401 US at 38-39 (noting that the plaintiff had argued that the application of state criminal law to the conduct in question would violate his First Amendment rights).

107 See Part III.A.1.

108 See Younger, 401 US at 44 ("[C]omity ... will fare best if the States and their institutions are left free to perform their separate functions in their separate ways."). 
contrast, Ruhrgas and subject matter dismissals involve private, civil litigants, whose state law claims have not passed through a state decisionmaking filter. If a state's interest in adjudicating these cases is less, the remedy proposed in this Comment to protect that interest is proportionally less drastic. While litigants who seek a declaratory judgment, with the possibility of precluding relitigation in a state criminal prosecution, cannot in Younger situations originally bring their actions at all in federal court, litigants seeking Ruhrgas and subject matter jurisdiction dismissals are entitled to a federal forum. ${ }^{109}$ The determinations of federal courts in these situations would merely be of limited preclusive effect. Federal courts, by abstaining preclusively as opposed to just abstaining, would offer a more targeted protection to the state interest at stake.

\section{Preclusive abstention after Ruhrgas.}

The question remains whether preclusive abstention, for dismissals from federal court for lack of personal jurisdiction while explicitly deferring or not addressing subject matter jurisdiction, is still tenable after Ruhrgas. The cheap answer is that Ruhrgas is not about the preclusive effect of such dismissals at all, but only the power to dismiss. However, preclusive abstention would be imperiled if clearly against the force of the Court's reasoning in Ruhrgas. The fate of preclusive abstention depends on the comparative merits of two alternative readings of Ruhrgas. The first reading emphasizes allowing federal courts efficiently to limit the scope of their own power. The second reading emphasizes litigants' rights to have a federal forum adjudicate important federal rights.

On the first reading, subject matter jurisdiction lacks dispositional priority over personal jurisdiction because both pertain to the power of the federal court to rule on the merits. ${ }^{11}$ In this sense, Ruhrgas is consistent with prior Court opinions requiring federal courts to decide questions of subject matter jurisdiction before proceeding to easier grounds on the merits which would also lead to dismissal. ${ }^{11}$

109 The reason why this more measured approach is not taken in Younger cases is likely because of the Article III floor requiring some preclusive effect, see text accompanying notes 10105 .

110 This is not to say that preclusive abstention offers no promise in any Younger situation. Consider Doran v Salem Inn, Inc, 422 US 922 (1975).

111 See Ruhrgas, 526 US at 584 ("Personal jurisdiction, too, is 'an essential element of the jurisdiction of a district ... court,' without which the court is 'powerless to proceed to an adjudication."'), quoting Employers Reinsurance Corp v Bryant, 299 US 374, 382 (1937).

112 See Steel Co v Citizens for a Better Environment, 523 US 83, 93-94 (1998) (rejecting the availability of "hypothetical jurisdiction" to decide the case on the merits even when straightforward and resulting in dismissal). 
This Comment's claim that subject matter jurisdiction is a necessary condition for federal court decisions to have an intersystem preclusive effect ${ }^{13}$ is entirely consistent with this first "judicial power" rationale for Ruhrgas. A federal court has "jurisdiction to determine its own jurisdiction." ${ }^{114}$ Here, a federal court involved in a Ruhrgas dismissal would have the jurisdiction to decide its own jurisdiction and nothing else, including the jurisdiction of a state court.

Moreover, the Court reasoned that Ruhrgas dismissals preserve judicial economy by allowing federal courts to avoid labor intensive and complex subject matter jurisdiction objections when there is an easier route to the same result - the clearing of the case from federal court. $^{115}$ Limiting the preclusive effect of a Ruhrgas dismissal would not affect intrasystem judicial economy.

The second reading of Ruhrgas is that the limits on a state or federal court's exercise of personal jurisdiction represent important federal rights and a litigant is entitled to a federal court's preclusive adjudication, notwithstanding the uncertainty of subject matter jurisdiction. If this were the force of the court's reasoning, then preclusive abstention would be untenable because state courts would not adequately protect the defendant's federal rights.

This reading, however, would prove far too much. If the protection of federal rights were sufficient to justify a federal adjudication of those rights preclusive in state court, then several well-established subject matter jurisdiction rules, which prevent addressing some federal rights, would be invalid. For example, the well-pleaded complaint rule, interpreting the statutory scope of federal question jurisdiction, prevents federal courts from finally adjudicating federal rights which appear in the form of a defense or a reply to a defense as opposed to

113 Compare intrasystem preclusion. Under federal preclusion law prior to Ruhrgas, a dismissal for lack of subject matter jurisdiction would preclude relitigation of subject matter jurisdiction in another federal court. See, for example, Dozier v Ford Motor Co, 702 F2d 1189, 1191 (DC Cir 1983) (noting that subject matter jurisdiction dismissal precludes assertion of such jurisdiction in another federal court).

114 See note 126 and accompanying text.

115 See Ruhrgas, 526 US at 587-88 (noting that, in part, judicial economy supports the result).

116 At first cut, limiting the scope of issue preclusion might appear to increase judicial costs for state courts by forcing them to redecide the personal jurisdiction question. This ignores the more subtle dilemma that federal courts would face between intersystem economy and sensitivity to federalism interests. If Ruhrgas dismissals were only preclusive when the federal court had subject matter jurisdiction, then state courts would need to parse through the complex and unfamiliar subject matter jurisdiction issue. This would increase judicial costs even more than forcing the state courts to redecide the easier personal jurisdictional issue. If, on the other hand, Ruhrgas dismissals were preclusive when the federal court lacked subject matter jurisdiction, the rendering court would run roughshod over the federalism concerns illustrated in Part III.A. This Comment's approach would preserve intrasystem judicial economy and strike the appropriate balance between intersystem judicial economy and federalism. 
part of the cause of action. ${ }^{117}$ These federal rights so excluded can be, perhaps like personal jurisdiction, of constitutional importance. ${ }^{118}$

The adjudication of federal rights is deferred to state court, at least in the case of the well-pleaded complaint rule, in the clear absence of subject matter jurisdiction. Here, subject matter jurisdiction is never decided. Preclusive abstention, when combined with the power of federal courts under Ruhrgas, would leave a state court defendant without a federal forum to which she may be entitled. That is, if the major premise of this Comment is correct, that subject matter jurisdiction is the power of federal courts to issue determinations of law and fact preclusive in state court, then the litigant may be entitled to intersystem preclusion. However, it would not be the first time that federal courts have abdicated their responsibility finally to adjudicate even amidst statutorily conferred subject matter jurisdiction. ${ }^{119}$ In fact, in other abstention cases, federal courts clearly possessed subject matter jurisdiction. Even a clear conferral of subject matter jurisdiction does not entitle a litigant to a federal forum. ${ }^{120}$ In Ruhrgas dismissals, where subject matter jurisdiction is far from clear, the litigants clearly lack an entitlement to a federal forum.

\section{B. The Limits of a Federal Court's "Jurisdiction to Determine Its Own Jurisdiction" and Narrowly Defining the "Precise Issue of Jurisdiction"}

Federal courts already have the legal apparatus with which to implement preclusive abstention amidst uncertainty regarding subject

117 See Louisville \& Nashville Railroad Co v Mottley, 211 US 149, 152 (1908) ("[A] suit arises under the Constitution and laws of the United States only when the plaintiff's statement of his own cause of action shows that it is based upon those laws or that Constitution.").

118 See id (foreclosing original federal adjudication of the constitutionality of a federal statute offered as a defense to a state law breach of contract action). Indeed, the rights relegated to state courts by the well-pleaded complaint rule affect litigants' primary obligations rather than merely how (or where) those obligations will be adjudicated.

119 See, for example, Railroad Commission of Texas v Pullman Co, 312 US 496, 498 (1941) (abstaining from the determination of federal rights in the face of difficult predicate state law questions).

120 See, for just a few examples, id (where the federal court clearly had jurisdiction over the constitutional question of whether the employment policy violated the Equal Protection Clause); Younger, 401 US at 40-41 (where the federal court clearly had jurisdiction over the cause of action that the state prosecution violated the defendants' First Amendment rights, but abstained from proceedings nonetheless); Burford v Sun Oil Co, 319 US 315, 322 (1943) (abstaining from intervention in a complex state administrative scheme notwithstanding presence of a clear federal question).

121 In this sense, the form of preclusive abstention here does not present the separation of powers problem, in ignoring Congress's careful weighing of federalism concerns in statutorily conferring subject matter jurisdiction, that cases like Pullman present. For a more complete exposition of these separation of powers problems, see generally Martin H. Redish, Abstention, Separation of Powers and the Limits of the Judicial Function, 94 Yale L J 71 (1984). 
matter jurisdiction. The traditional rule is that a jurisdictional dismissal is issue preclusive only with regard to the "precise issue of jurisdiction." "22 Unfortunately, to state the rule is not to apply it. Precision is a distinction of degree rather than kind. The "precise issue" rule could mean that a dismissal for lack of jurisdiction would not preclude relitigation of all matters decided before dismissal. However, if that were the case, there would be nothing special about jurisdictional dismissals. General rules of issue preclusion restrict the preclusive effect of any judgment to only those issues which were "actually litigated" and "necessarily decided." "23 Under those rules, any ruling before dismissal which was not necessary for determining the lack of jurisdiction would not be issue preclusive. The fact that there is a separate test for jurisdictional dismissals suggests that the preclusive effect is narrower than the general rules would indicate.

Courts have not approached the question of what "precise" means with precision. Some have suggested that the preclusive effect extends to holdings on the merits necessary to finding a lack of jurisdiction. ${ }^{124}$ Other courts have held that the preclusive effect of jurisdictional dismissal cannot extend to any issue on the merits, regardless of whether the issue is logically prior to jurisdiction. Accordingly, these courts have held that the preclusive effect of a jurisdictional dismissal is limited to the issue of jurisdiction itself. ${ }^{125}$ When subject matter juris-

\section{See notes $124-26$.}

123 See note 42.

124 See, for example, Oglala Sioux Tribe of Pine Ridge Indian Reservation v Homestead Mining $\mathrm{Co}, 722 \mathrm{~F} 2 \mathrm{~d} 1407,1412$ (8th Cir 1983) (precluding relitigation of the constitutionality of a statute determined in the course of a jurisdictional dismissal); Dozier v Ford Motor Co, 702 F2d 1189,1198 (DC Cir 1983) (Wald dissenting) (suggesting that a failure to satisfy the jurisdictional amount requirement of 28 USC $\$ 1332$ (a) because of the unavailability of punitive damages precludes the recovery of punitive damages in later litigation, but not discussing the "precise question of jurisdiction" rule); Segal v American Telephone \& Telegraph Co, 606 F2d 842, 844-45 (9th Cir 1979) (holding that a jurisdictional dismissal forecloses those issues of law and fact actually litigated and necessarily decided by a final judgment); Roth v McAllister Bros, Inc, 316 F2d 143, 145 (2d Cir 1963) (estopping defendant from denying that plaintiff was a seaman when a prior court's finding that plaintiff was a seaman constituted a material fact that was the sole basis of dismissal for lack of jurisdiction in the prior court). See also Charles Alan Wright, Arthur R. Miller, and Edward H. Cooper, 18 Federal Practice and Procedure $\S 4436$ at 340 (West 1981) (stating without authority that "[a]lthough a dismissal for lack of jurisdiction does not bar a second action as a matter of claim preclusion, it does preclude relitigation of those issues determined in ruling on the jurisdiction question").

125 See North Georgia Electric Membership v City of Calhoun, 989 F2d 429, 433 (11th Cir 1993), quoting Wright, Miller, and Cooper, 18 Federal Practice and Procedure $\S 4436$ at 338 (cited in note 124) ("The judgment remains effective to preclude relitigation of the precise issue of jurisdiction or venue that led to the initial dimissal."); Casey v Department of State, 980 F2d 1472, 1475 \& $n 3$ (DC Cir 1992) (holding that jurisdictional dismissals do not preclude all issues litigated, but only "the precise issue of jurisdiction"); GAF Corp v United States, 818 F2d 901, 91213 (DC Cir 1987) (holding that facts underlying jurisdictional dismissal can be relitigated under certain circumstances); Cutler v Hayes, 818 F2d 879, 889 (DC Cir 1987) (holding that dismissal for lack of standing estops assertion of standing in federal court). See also Hopwood $v$ Texas, 78 
diction is absent or uncertain, the preclusive effect of a jurisdictional dismissal ought to be confined to only the question of jurisdiction, and not extended to determinations of facts and law on the merits necessary for the dismissal, for two reasons.

First, the preclusive effect of jurisdictional dismissals should conform with the power the court exercises in determining its own jurisdiction. A federal court always has "jurisdiction to determine its own jurisdiction." ${ }^{126}$ However, that jurisdiction, by its terms, is a conferral of power for a very limited purpose: determining whether the court may go forward to adjudicate the merits. ${ }^{127}$ When a federal court finds that it has no subject matter jurisdiction, the preclusive effect of that determination should be sensitive to what the court lacks, the power finally to determine the merits.

Second, the power to determine "its own jurisdiction" should also imply that it has no jurisdiction to determine the jurisdiction of other courts. ${ }^{128}$ Attaching a preclusive effect to Ruhrgas dismissals would permit a federal court to act ultra vires by determining not only its own personal jurisdiction, but also the personal jurisdiction of the courts of the state in which the federal court sits.

Personal jurisdiction in federal and state courts is not entirely the same question. In Ruhrgas, the Supreme Court, when discussing the comparative importance of subject matter and personal jurisdiction, noted that limitations on personal jurisdiction are often constitutional, depending on the Due Process Clause of the Fourteenth Amendment. ${ }^{129}$ Subject matter jurisdiction limitations, in contrast, are often statutory: ${ }^{130}$ The Court found that the ability of courts to raise subject matter jurisdiction sua sponte is not an indication of its fundamentality, but a realization that litigants may not adequately protect the institutional interests which subject matter jurisdiction protects. ${ }^{131}$ The con-

F3d 932, 961 (5th Cir 1996) (noting that "dismissals for lack of jurisdiction normally do not have preclusive effect" but for the issue of jurisdiction itself).

126 See Steel Co v Citizens for a Better Environment, 523 US 83, 118 (1998) (emphasis added). See also United States $v$ United Mine Workers, 330 US 258, 292 n 57 (1947) (noting that federal courts may also need to consider matters of law and fact to determine jurisdiction).

127 See Insurance Corp v Compagnie Des Bauxites, 456 US 694, 701-02, 706-07 (discussing the reasons for the proceedings for which a federal court is authorized to determine jurisdiction).

128 Steel $\mathrm{Co}, 523 \mathrm{US}$ at 118.

129 See 526 US at 584 . This was particularly true in Ruhrgas because Texas, from which the action was originally removed, had an unenumerated long arm statute, extending personal jurisdiction to the limits of the Fourteenth Amendment. Id at 580.

130 See, for example, Strawbridge $v$ Curtiss, 7 US (3 Cranch) 267, 267 (1806) (requiring complete diversity as an interpretation of what is today 28 USC $\$ 1332)$; Louisville \& Nashville Railroad Co v Mottley, 211 US 149, 152 (1908) (interpreting 28 USC $\$ 1331$ to require the federal question to appear in a well-pleaded complaint).

131 See Ruhrgas, 526 US at 583 (holding that a court's ability to raise subject matter jurisdiction sua sponte does not make it most fundamental). See also Marathon Oil v AG Ruhrgas, 145 F3d 228-29 (5th Cir 1998) (en banc) (Higgenbotham dissenting) (noting the institutional inter- 
stitutional source of personal jurisdiction rights possibly makes personal jurisdiction more fundamental in certain cases. ${ }^{132}$

While the Court is correct that personal jurisdiction concerns are sometimes constitutional, it is crucial to be clear about the source of limits on personal jurisdiction in federal court for defining the "precise issue" determined when federal courts dismiss for want of personal jurisdiction. Federal courts are not limited directly by the minimum contacts analysis of the Fourteenth Amendment, which applies only to states. Rather, the personal jurisdiction of federal courts is constrained by the Due Process Clause of the Fifth Amendment. ${ }^{1.33}$ Thus, if Congress so desired, it could provide for personal jurisdiction in federal courts subject only to the limitation that the defendant have minimum contacts with the United States, not any particular state. ${ }^{134}$ What makes the state question of personal jurisdiction relevant is Congress's decision, through the Federal Rules of Civil Procedure, to limit a federal district court's personal jurisdiction to only those persons "who could be subjected to the jurisdiction of a court of general jurisdiction in the state in which the district court is located."

Furthermore, the statutory source of personal jurisdiction limits in federal courts suggests that federal courts are simply parsing their authority through Rule $4(\mathrm{k})(1)(\mathrm{A})$ when they dismiss. A different source of a legal right, even if ostensibly applying the same legal standard, is a difference which makes a difference with regard to issue preclusion in general. ${ }^{136}$ We should be all the more exacting about the

ests subject matter jurisdiction protects).

132 See Ruhrgas, 526 US at 584; Marathon Oil, 145 F3d at 228-29 (en banc) (Higginbotham dissenting) (explaining that subject matter jurisdiction does not have an "elevated status" above personal jurisdiction).

133 See notes 31, 134.

134 See Point Landing, Inc v Omni Capital International, Ltd, 795 F2d 415, 426 (5th Cir 1986) (noting that the Fifth Amendment constitutional limit of federal court personal jurisdiction would not be tied to any one state). In fact, Congress has provided for national contacts limitations in some circumstances. See, for example, 28 USC $\$ 1335$ (1993) (granting federal courts interpleader jurisdiction); FRCP $4(k)(1)(C)$ (establishing personal jurisdiction over any person subject to federal interpleader jurisdiction).

135 FRCP 4(k)(1)(A). Limiting federal personal jurisdiction through the Federal Rules of Civil Procedure may seem odd given that the rules may not abridge or expand the jurisdiction of federal courts. See Rules Enabling Act, 28 USC \& 2072(b) (1994). However, no other congressional statute grants federal courts broader personal jurisdiction and federal courts may, in general, only exercise that jurisdiction which is specifically granted by Congress. See Sheldon $v$ Sill, 49 US ( 8 How) 441, 448-49 (1850) (holding that the jurisdiction of at least lower federal courts must be affirmatively granted by congressional statute as well as within constitutional limits). Thus Rule 4(k)(1)(A) does not "abridge" the personal jurisdiction of federal courts. It may enlarge it from no personal jurisdiction. But Congress likely intended federal courts to have some personal jurisdiction.

136 See, for example, Shriners' Hospitals for Crippled Children v United States, $14 \mathrm{Cl} \mathrm{Ct} 51$, 55 (1987) (holding that a previously decided issue of state law did not preclude the relitigation of a federal law question despite the identity of the legal standard), revd on other grounds, 862 F2d 
definition of the issue where subject matter jurisdiction is at least uncertain. ${ }^{137}$ When the different sources for personal jurisdiction limitations - Rule 4 for federal courts and each state's long arm statute coupled with the Fourteenth Amendment for state courts-are considered with a federal court's limited power to determine its own jurisdiction, the precise issue of jurisdiction in Ruhrgas dismissals should be defined as the federal court's interpretation of its statutory personal jurisdiction limits, not as precluding a state court's independent interpretation of its own jurisdiction. ${ }^{138}$

\section{Preclusive Sensitivity to the Process of Determining Jurisdiction}

Preclusion depends in large part on the assumption that the rendering court fully considered the issues that were necessary to its disposition of the case. The manner in which jurisdictional dismissals are typically decided, however, should often inspire skepticism about attaching a significant preclusive effect.

\section{Removal and remand.}

Many jurisdictional dismissals from federal court arise after a defendant in state court has removed the case to federal court. ${ }^{139}$ The increased occurrence of jurisdictional arguments in removal cases may be a function of the express divergence of the parties on where they wish to litigate. ${ }^{\text {140 }}$ If a federal court finds that it lacks subject matter jurisdiction over a removed action, ${ }^{141}$ it will remand the case to the state court from which it was removed. ${ }^{142}$ In Ruhrgas, the court rejected arguments that it should not permit personal jurisdiction dismissals before subject matter jurisdiction particularly in removal cases, because

1561 (Fed Cir 1988).

137 See Part III.A.

138 Moreover, the issue to be precluded is defined by the law of the rendering court, that is, federal law, if Part II is correct. See Blackwelder v Millman, 522 F2d 766, 772-73 (4th Cir 1975) (holding that the scope of the issue precluded by a judgment is determined by the law of the court rendering that judgment).

139 See 28 USC \& 1441 (1994) (granting removal jurisdiction over cases filed in state court, but removed by the defendant, over which federal courts would have had original jurisdiction if the case were first filed in federal court).

140 Jurisdictional dismissals tend to occur frequently in the removal context because the parties disagree about the choices of forum: the plaintiff brought the case in the state court, and the defendant demanded a federal forum.

141 Of course, the federal court will only remand in the second case this Comment considers - when the court dismisses for lack of subject matter jurisdiction while deciding some other issues of fact and law. If courts dismiss on Ruhrgas grounds, the case will not be remanded to the original state court, but simply dismissed. See Rurhgas, 526 US at 578 (discussing the district court's dismissal on personal jurisdiction grounds).

142 See 28 USC $\$ 1447$ (1994) (specifying the procedures for remand). 
they constitute the greatest affront to state courts. ${ }^{143}$ While the power to dismiss on Ruhrgas grounds clearly extends to removal cases, any possible preclusive effect certainly should not be extended because of the procedural poverty of remand determinations.

Federal court remand orders are generally not appealable..$^{144}$ Accordingly, federal courts have been concerned about attaching an issue preclusive effect to remand orders, even among federal courts. ${ }^{145}$ With regard to judgments generally, the Supreme Court initially held that preclusion rules should not be sensitive to the lack of appealability of the first judgment. ${ }^{146}$ Gradually, courts have become more unwilling to attach preclusive effect to unappealable judgments. ${ }^{14}$

If we were in equipoise over whether federalism concerns require that the preclusive effect of dismissals amidst uncertainty regarding subject matter jurisdiction be limited to federal court, the lack of appellate review should break that tie in removal and remand cases.

\section{Proceedings short of a trial on the merits.}

Jurisdictional dismissals outside the removal jurisdiction context are often the subject of proceedings well short of a trial on the merits. While the Supreme Court has definitively held that the unavailability of a jury trial in the rendering court is insufficient to negate that judgment's preclusive effect, ${ }^{148}$ courts have not clearly spoken regarding the effect of proceedings short of a trial at all on issue preclusion. There has been some suggestion by the Court that determining questions on the merits, for purposes of determining jurisdiction, is

143 See 526 US at 585.

144 See 28 USC $\$ 1447$ (d).

145 See, for example, Winters v Diamond Shamrock Chemical Co, 149 F3d 387, 392-94 (5th Cir 1998) (holding that one federal court's order to remand for lack of subject matter jurisdiction cannot be the subject of non-mutual collateral estoppel). But see Williams v North Carolina, 325 US 226, 230 (1945) (noting that a jurisdictional dismissal can never be the subject of non-mutual collateral estoppel due to the authority of each court to decide its own jurisdiction). There is some question as to whether Williams survives Parklane Hosiery Co v Shore, 439 US 322, 331 (1979) (permitting non-mutual collateral estoppel while holding that courts should be more cautious generally in attaching such an effect).

146 See Johnson Co v Wharton, 152 US 252,261 (1894) ("The existence or non-existence of a right, in either party, to have the judgment in the prior suit re-examined, upon appeal or writ of error, cannot, in any case, control this inquiry.").

147 See Standefer $v$ United States, 447 US 10,23 \& n 18 (1980) (stating that the lack of appellate review "strongly militates against giving an acquittal preclusive effect"). In fact, the Restatement position is that there is an exception to preclusion generally when "[ $t$ ]he party against whom preclusion is sought could not, as a matter of law, have obtained review of the judgment in the initial action." Restatement (Second) of Judgments $\$ 28(1)$.

148 See Parklane Hosiery, 439 US at 332, 337 (noting that while an inconvenient forum might be enough to counsel against permitting non-mutual collateral estoppel, the lack of a jury trial is not). Presumably, in cases where the collateral estoppel is mutual, the Court's rule about the irrelevance of a lack of jury trial in the first proceeding would be even firmer. 
sufficiently different in procedure than determining the merits themselves so that jurisdictional dismissals ought not to constitute the final resolution of those questions. ${ }^{149}$ This may depend in large part on the perceived attitude of both the litigants and the court. The court is aware that a denial of jurisdiction still permits the litigants to find a proper forum. The litigants, because of the availability of state courts in the event of a loss, have less incentive vigorously to litigate the questions on the merits. ${ }^{150}$ Accordingly, the truncated procedure which often attends the determination of jurisdictional questions suggests that there ought to be a difference between determining questions on the merits and determining questions on the merits for purposes of jurisdiction. ${ }^{151}$

\section{CONCLUSION}

Federal courts should use their power to develop issue preclusion rules to abstain from precluding relitigation in state courts where subject matter jurisdiction has been denied or its determination has been explicitly deferred. Both of these cases fall outside the traditional rules of jurisdictional preclusion. While federal courts certainly have the power to determine their own jurisdiction, and accordingly clear cases from their dockets, the uncertainty of subject matter jurisdiction makes the power to preclude state relitigation equally uncertain. Even if the federalism protections embodied in subject matter jurisdiction are not sufficient to overcome a general judicial interest in finality, the austere procedural circumstances under which jurisdictional dismissals are generally determined should counsel against extending the preclusive effect of such dismissals beyond federal courts.

149 See NLRB v Denver Building \& Construction Trades Council, 341 US 675, 681-83 (1951) (holding that the determination that actions have no effect on interstate commerce for purposes of denying jurisdiction does not preclude litigation about the existence of an effect on interstate commerce for a question on the merits in another tribunal).

150 The Supreme Court has noted before that a low incentive to litigate in the rendering court counsels against preclusion. See Parklane Hosiery, 439 US at 330 . Admittedly, the incentive to litigate depends on the preclusion rule-if litigants know that intermediate holdings on the merits will be preclusive, their incentive to litigate will be high.

151 There is a powerful response here. Some merits questions in the jurisdictional context are held to even more exacting legal standards than if they were determined at a trial on the merits. For example, in order to find that the jurisdictional amount requirement of 28 USC $\S$ 1332(a) is not met, a federal court must find that damages in excess of $\$ 75,000$ are unavailable to a "legal certainty." See Saint Paul Mercury Indemnity Co v Red Cab Co, 303 US 283, 289 (1938) (discussing standards for amount in controversy requirement). It might be absurd to hold that while a certain class of damages is not available to a legal certainty, it is available as a simple matter of the merits. However, this leaves the problem of low litigation incentives, pervading all the issues in jurisdictional dismissals, unaffected. 